\title{
A Contribution of GIS Methods to Assess the Aquifer Vulnerability to Contamination: A Case Study of the Calcareous Dorsal (Northern Rif, Morocco)
}

\author{
Rabie El Bardai, Kamal Targuisti, Khadija Aluni \\ Departement of Geology, University of Abdelmalek Essaâdi, Tetouan, Morocco \\ Email: relbardai@gmail.com
}

Received 16 February 2015; accepted 9 April 2015; published 13 April 2015

Copyright (C) 2015 by authors and Scientific Research Publishing Inc.

This work is licensed under the Creative Commons Attribution International License (CC BY). http://creativecommons.org/licenses/by/4.0/

(c) (i) 0pen Access

\begin{abstract}
Karst groundwater constitutes the main resource for drinking water supply in Chefchaouen region, North Morocco. However, the karstic aquifers are highly vulnerable to the pollution because of the deforestation which favors the soil erosion and the landslides. Therefore, the groundwater is loaded with suspended sediment. The fertilizers disseminated for agriculture can also infiltrate and concentrate in the saturated zone of the aquifer. In this study, the geographic information system (GIS) provides an effective tool for groundwater contamination risk assessment, because it facilitates multicriteria analysis and updates the models developed. The EPIK model based on GIS uses four environmental parameters (Epikarst, Protective cover, Infiltration condition and Karst network development) to evaluate the intrinsic vulnerability of groundwater contamination potential. Each of these parameters is presented as a thematic map. After adding all data, the final result provides vulnerability map according to the protection factor relation based on which the protection zones' map is created.
\end{abstract}

\section{Keywords}

GIS, Groundwater, Vulnerability, Karst, EPIK

\section{Introduction}

Carbonate rock outcrops, of which a large part is karstified, cover about $7 \%$ - $12 \%$ of the planet's dry, ice-free land, and karst waters supply about $25 \%$ of the global population [1]. In Morocco, the Karst groundwater is a 
very important source of drinking water supply for many regions. In fact, they contain 70 percent of the water resources [2].

Decreasing availability, declining quality, and growing demand for fresh water are creating significant challenges. The balance between demand (consumption) and supply (resource) is becoming untenable. More than 30 countries suffer from serious chronic water shortage, and groundwater is increasingly being used to cover the demand [3]. The study area is mostly composed of limestone in which the huge water reserves constitute the largest water tower in northern Morocco. Some spring water discharges increase due to rain or snowmelt, exceeding 100 liters per second.

Karst aquifers are considered to be highly vulnerable to pollution as a result of their particular structure; hence it appears that the supply is made by a dispersed input and the discharge- - by a concentrated output. Due to this fact, contaminant elements' attenuation doesn't take place effectively, as in porous aquifers [4].

In order to map the groundwater vulnerability, karstic aquifers near to Chefchaouen city (Northern Rif, Morocco) were selected to test the sensitivity of vulnerability to selected values of ratings and weight in the EPIK method based on a Geographic Information System (GIS). It is considered as the first method taking into account the specific properties of karst [4] [5]. The acronym stands for the four factors that are considered: Epikarst (E), Protective cover (P), Infiltration conditions (I) and Karst network development (K).

\section{Study Area}

The study area forms part of the Septentrional Internal Rif. It corresponds to the segment of the external Calcareous Dorsale located precisely between the Oued Laou valley in the north, and the major fault of Jebha-charafate in the south (Figure 1). It consists of three stacked tectonic units: Jbel Tissouka unit, Jbel Lakraa unit, and

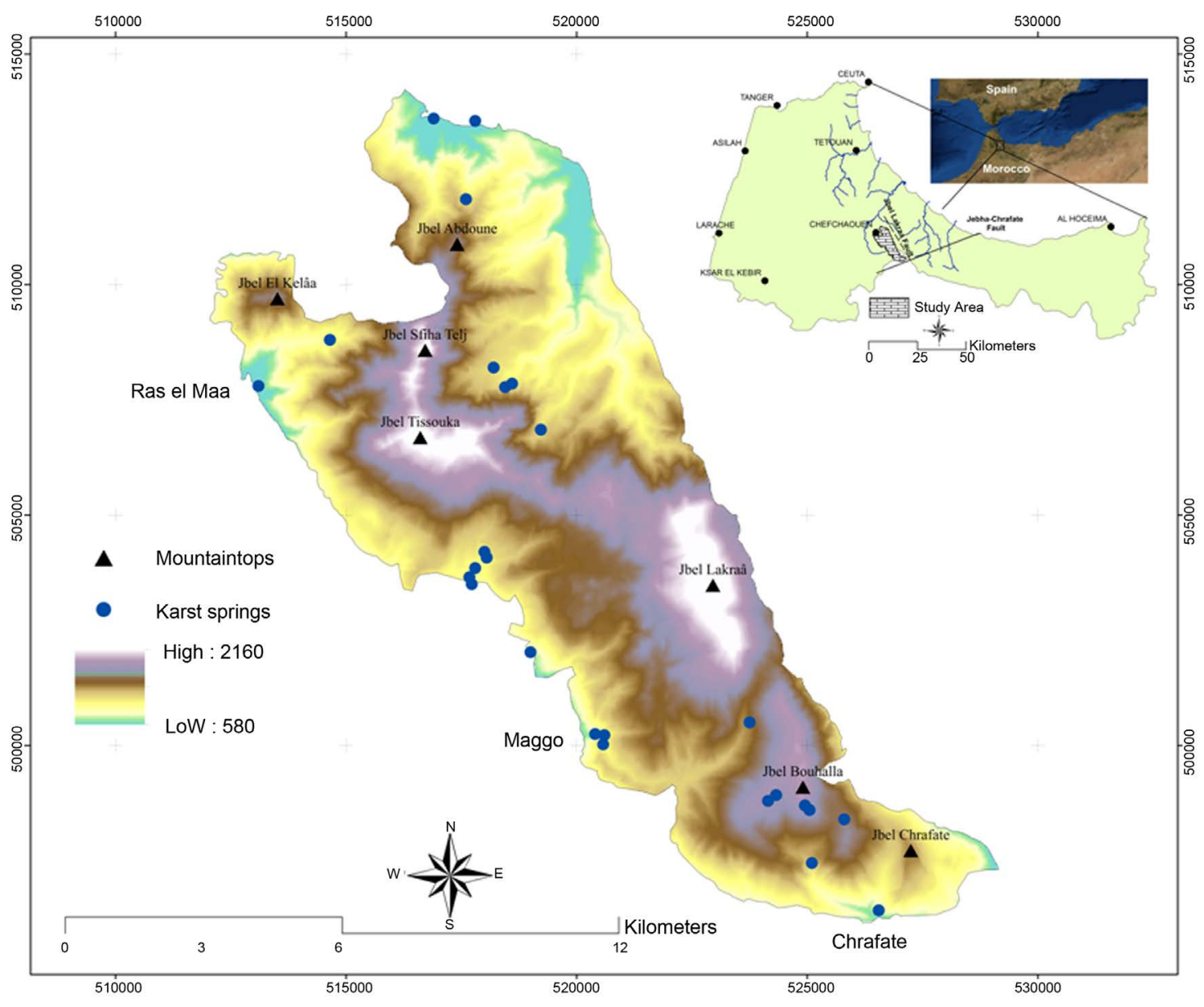

Figure 1. Location map and DEM (Digital Elevation Model) of study area. 
the Jbel Bouslimane unit, where some peaks exceed 2000 meters in high (2122 m in Jbel Tissouka and 2159 m in Jbel Lakraa).

\section{Geological and Hydrogeological Setting}

The units of study area are stacked in nappes with tectonic contacts dipping westward [6]. They are separated from the massif of Jbel Tazout by the directed NW-SE fault of Jbel Lakraa. The stratigrafic successions of the Calcareous Dorsal are described from bottom to top as [6] (Figure 2):

- Up to $900 \mathrm{~m}$ in thick of Carnian to Norian stromatolitic dolostones with intercalations of marly limestone;

- 80 to $300 \mathrm{~m}$ of limestone and dolomite alternation (Rhetian);

- Massive limestone and/or dolomite, their attribution to the Hettangian age is not strictly deducted;

- Flint limestone with marls and bituminous facies and intraformational breccias (from Sinemurian to Pliensbachian);

- The radiolarites and breccias of Dogger-Malm age;

- The conglomeratic and brecciated formations of Tertiary.

Hydrogeologically, the study area is crossed by many superficial streams. In addition, several springs gush at the foot of the limestone ridge, while others are dispersed geographically in the different formations. The most important springs are: Ras El Maa Spring located at west of the Jbel Tissouka unit whose it rises in the flint limestone; Ahramen and Aayaden Springs welling in massive carbonate formations of Hettangian age; and Chrafate Spring which is part of the Bouslimane unit and that gushes in the flint limestone of Pliensbachian age. For the whole area, these sources are the main water resources for both drinking water and irrigation.

Moreover, the rose diagram of hydrographic network (Figure 3) shows that N40-N50 oriented fractures pre-

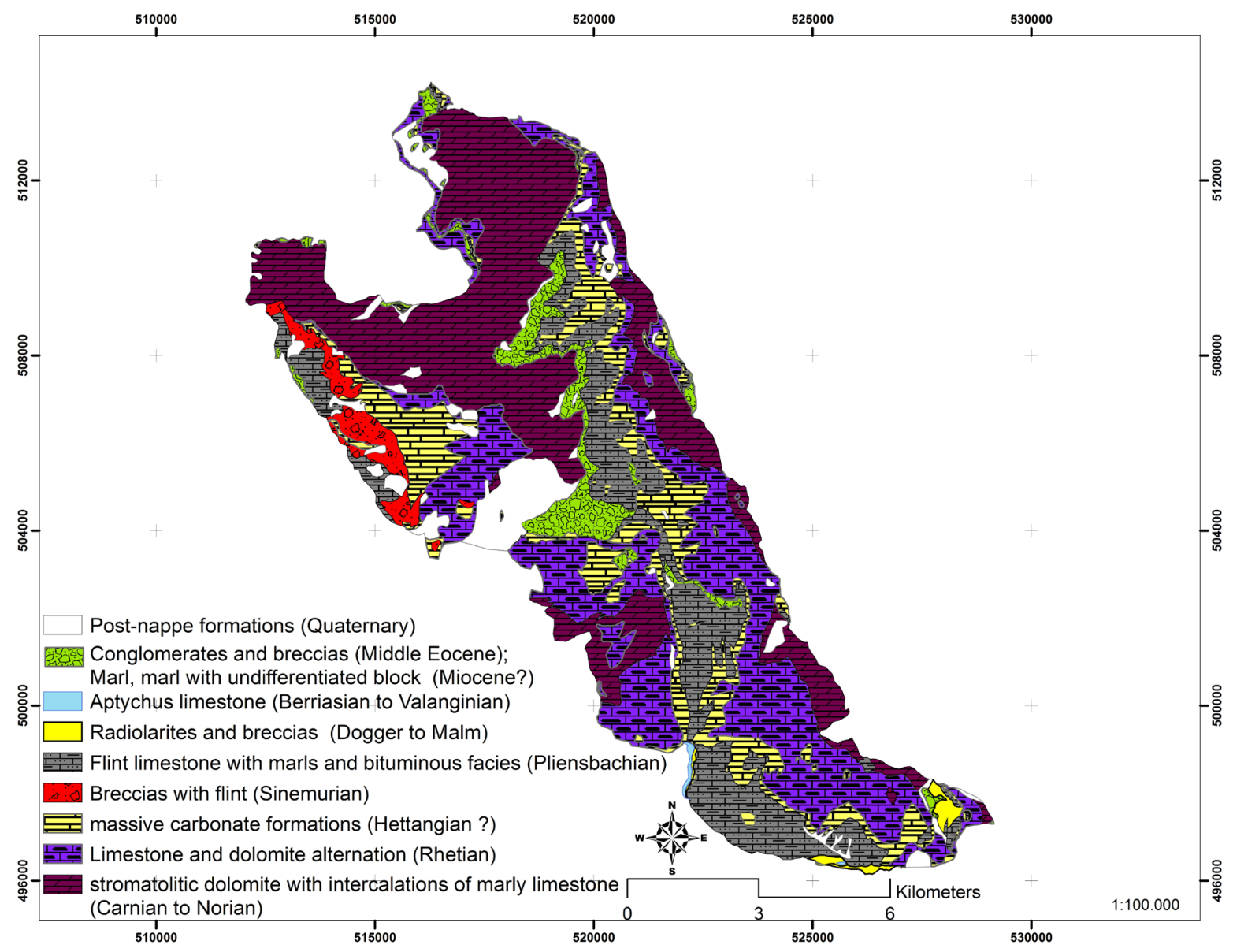

Figure 2. Geological map of the study area. 


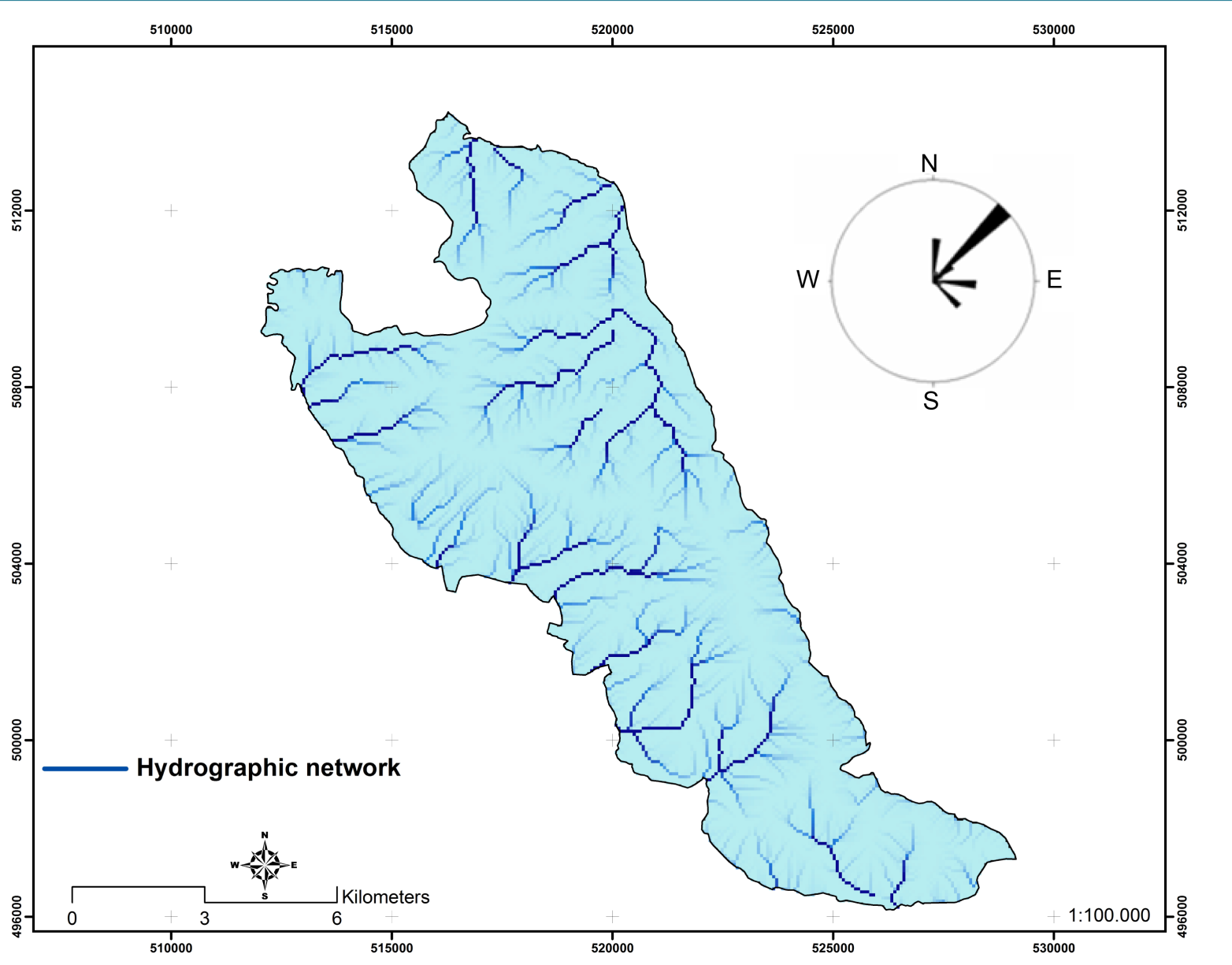

Figure 3. Surface water network map.

sents the most dominant class which seems to be linked to the crossover network faults associated with N60N80 direction of the Jebha-Chrafate major fault [7].

\section{The EPIK Method}

In case of groundwater resources, vulnerability map of the aquifers are an important tool for the groundwater management and protection [8]. Groundwater vulnerability defines the sensitivity of a groundwater source to contamination. Intrinsic vulnerability refers to the potential risk for contamination independent of the type of contaminant, while specific vulnerability considers the physico-chemical properties of the contaminant, mainly transit times, dispersion, degradation and decay of a specific contaminant etc. In this report, the term vulnerability refers to groundwater vulnerability to pollution [9]. In order to evaluate vulnerability mapping in the study area we use a multiparameter method called EPIK. It was defined in Switzerland to be applied only to the vulnerability assessment of karst aquifers [4] [10]. Four attributes are of main importance in this method, mainly Epikarst (E), Protective cover (P), Infiltration condition (I), and Karst network (K). Their evaluation is outlined in Table 1. Each parameter was attributed a weighting factor (Table 2) and a summation of the four layers allows to calculate a protection index value $\mathrm{F}$, which varies from 9 to 34 . The calculation is carried out as follows:

$$
\mathrm{F}=\alpha \mathrm{E}_{i}+\beta \mathrm{P}_{j}+\gamma \mathrm{I}_{k}+\delta \mathrm{K}_{l}
$$

where $\alpha, \beta, \gamma, \delta$ : Weighting coefficient of each parameter and $\mathrm{E}_{i}, \mathrm{P}_{j}, \mathrm{I}_{k}, \mathrm{~K}_{l}$ : Categories of each parameter.

All data collected for this study were converted into digital format to be implemented in a Geographical Information Systems (GIS). A relational geodatabase was designed to permit the simultaneous analysis of all type of data. Taking this approach, the result is color-coded map representing areas of relative vulnerability to ground- 
Table 1. Evaluation of E, P, I, and K parameters (modified from [4]).

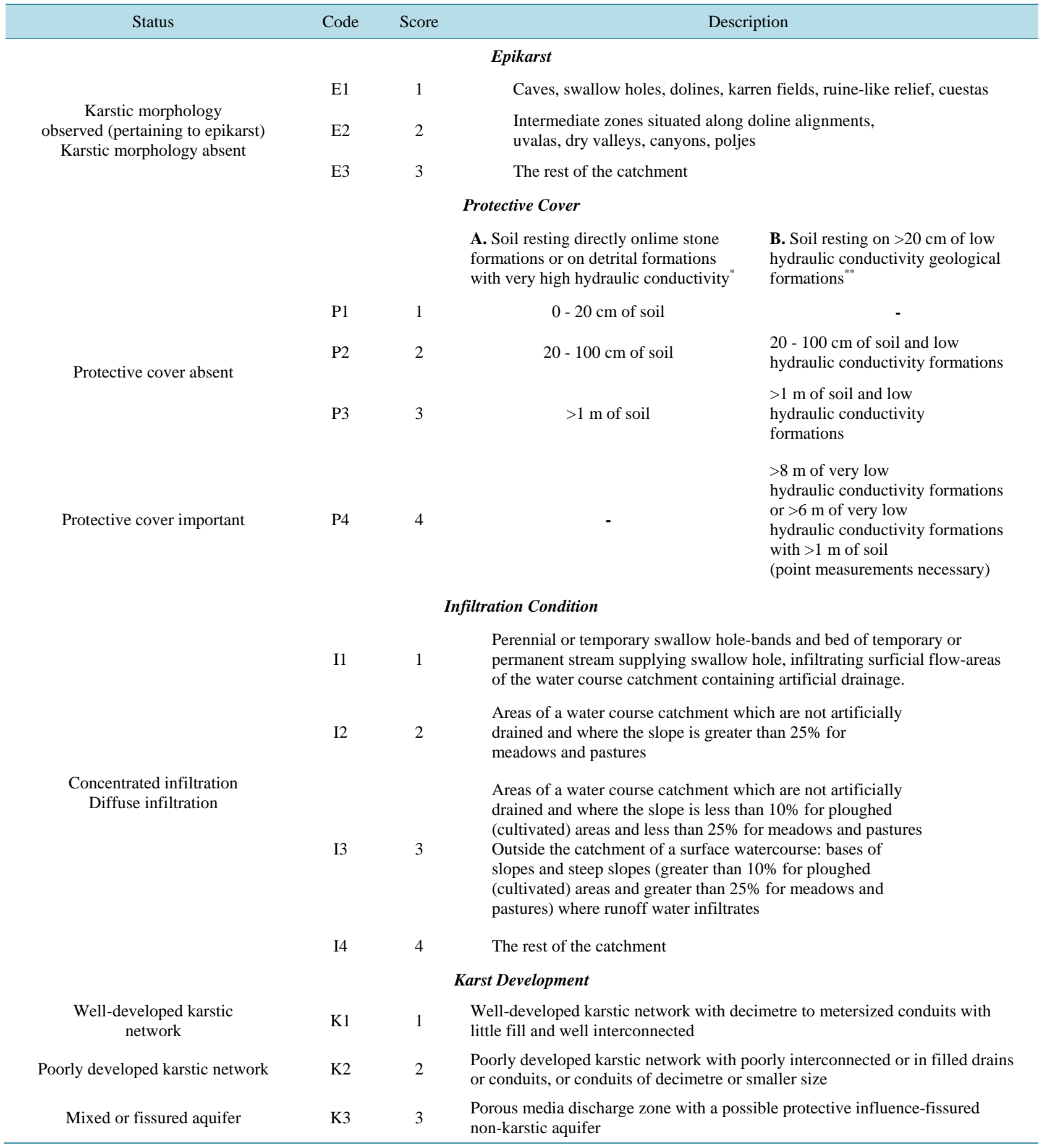

*Examples: scree, lateral glacial moraine; ${ }^{* *}$ Examples: silts, clays.

Table 2. Weighting coefficient attributed to the E, P, I and K parameters.

\begin{tabular}{ccccc}
\hline Parameter & $\mathrm{E}$ & $\mathrm{P}$ & $\mathrm{I}$ & \multicolumn{1}{c}{} \\
\hline Weighting coefficient & $\alpha$ & $\beta$ & $\gamma$ \\
Relative weight & 3 & 1 & 3 \\
\hline
\end{tabular}


water contamination from the surface, which also represent protection zone [11].

\section{Results and Discussion}

\subsection{Epikarst (E)}

The epikarst or subcutaneous zone is located at the top of the aerated or vadose zone in carbonate rocks. The vadose zone in karst comprises the soil (if there is any), the epikarst zone, and the transmission zone. From the epikarst, water percolates downwards through a zone dominated by transmission rather than storage that delivers recharge to the saturated or phreatic zone [12]. The epikarst parameter mapping was made using the interpretation of aerial photography, the field verification and geomorphological studies. These data have been georeferenced and implemented in a GIS-database.

According to [5] the Epikarst parameter is subdivided into three classes that indicate decreasing vulnerability as shown in Table 1. Morphological data were elaborated by a GIS to mapping these classes (Figure 4).

\subsection{Protective Cover (P)}

In our case, the protective cover mainly consists of soil and it included as well as other geological formation. The soil is resting directly on limestone formations. In order to assess the parameter $\mathrm{P}$, we used the slope map (Figure 5) generated from digital elevation model (DEM) in GIS system and the land-use map (Figure 6) which allowed to define the different soil classes along the study area according to their thickness (Table 1). Three P classes were then defined as shown in Figure 7.

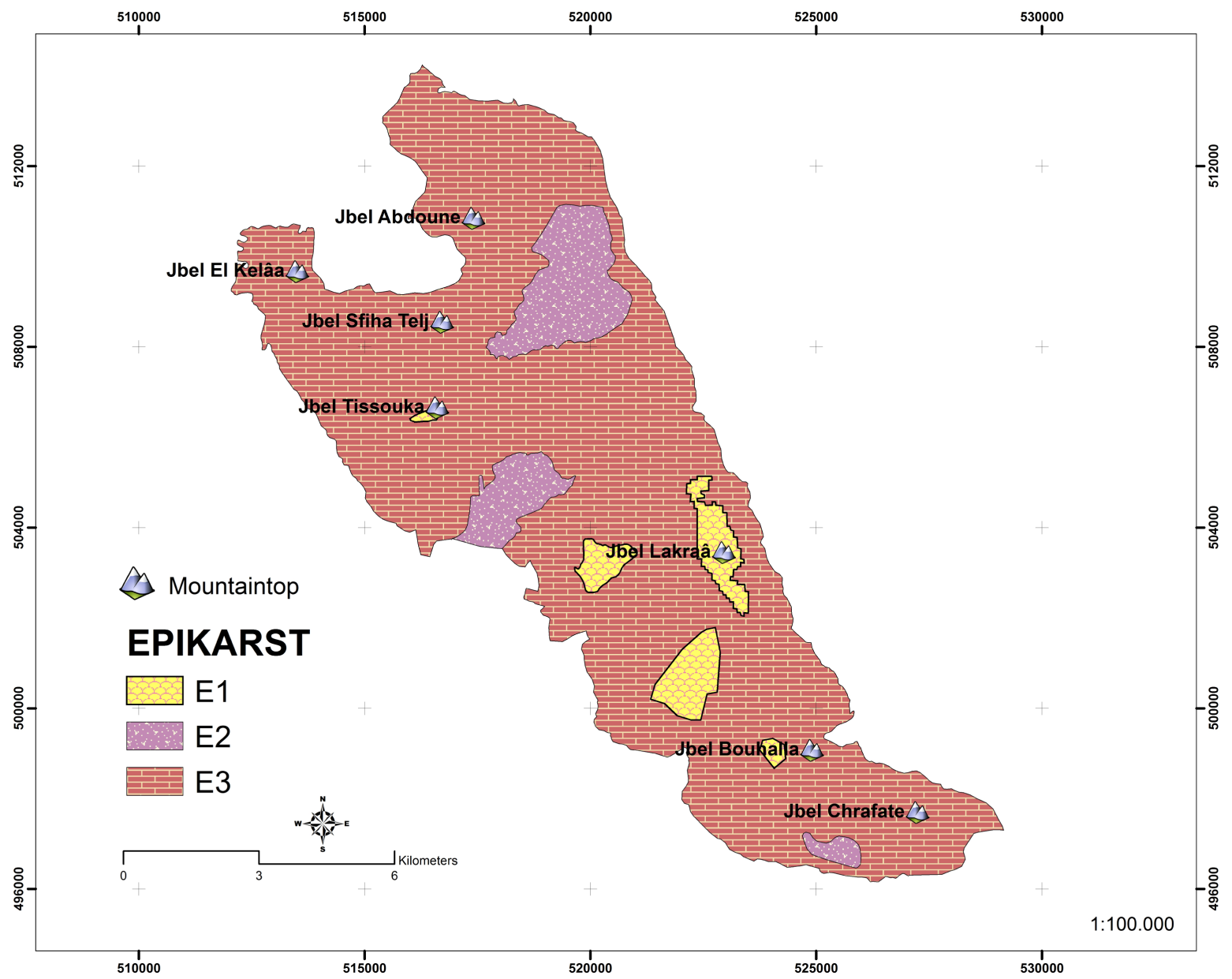

Figure 4. Epikarst map. 
R. El Bardai et al.

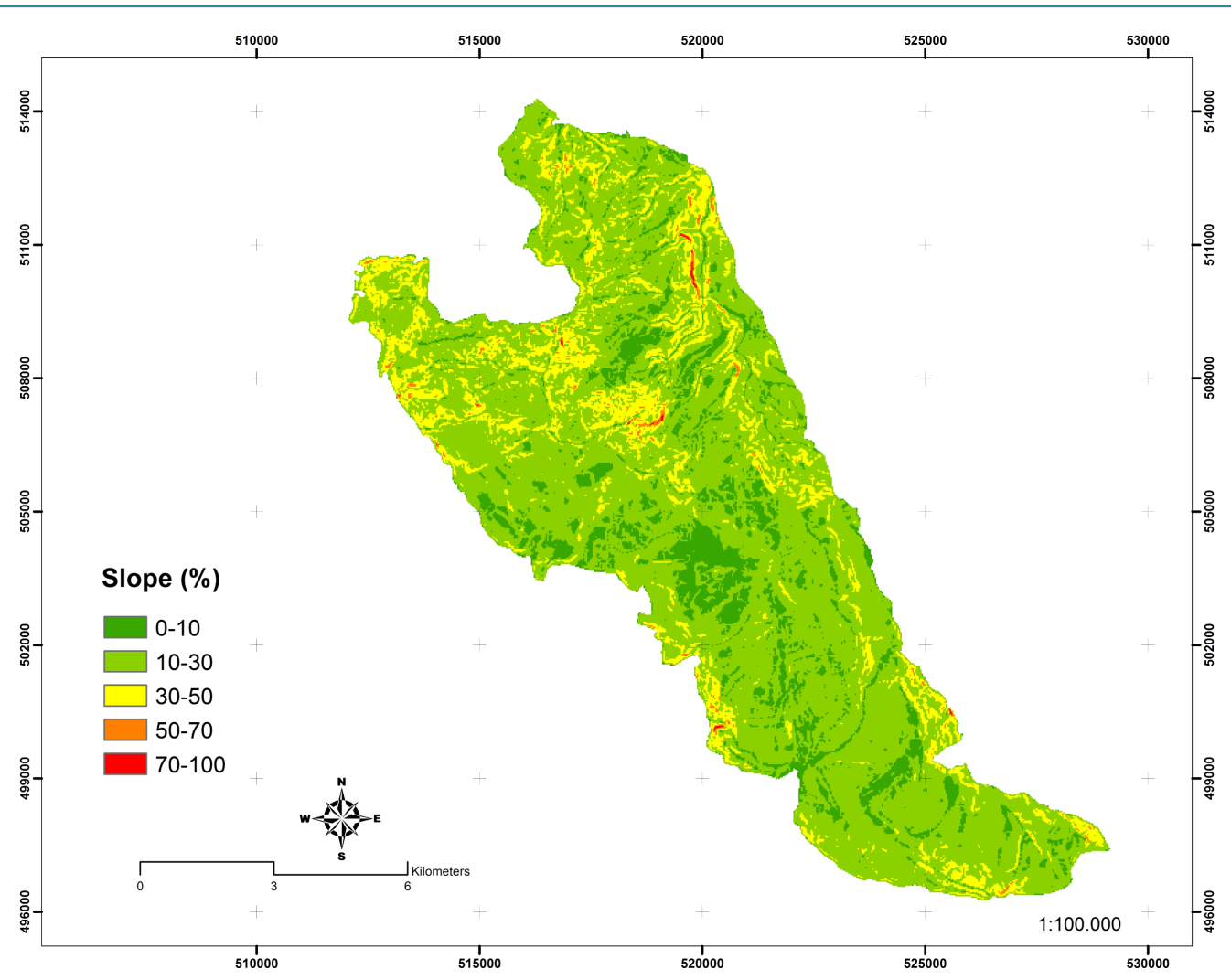

Figure 5. Slope map.

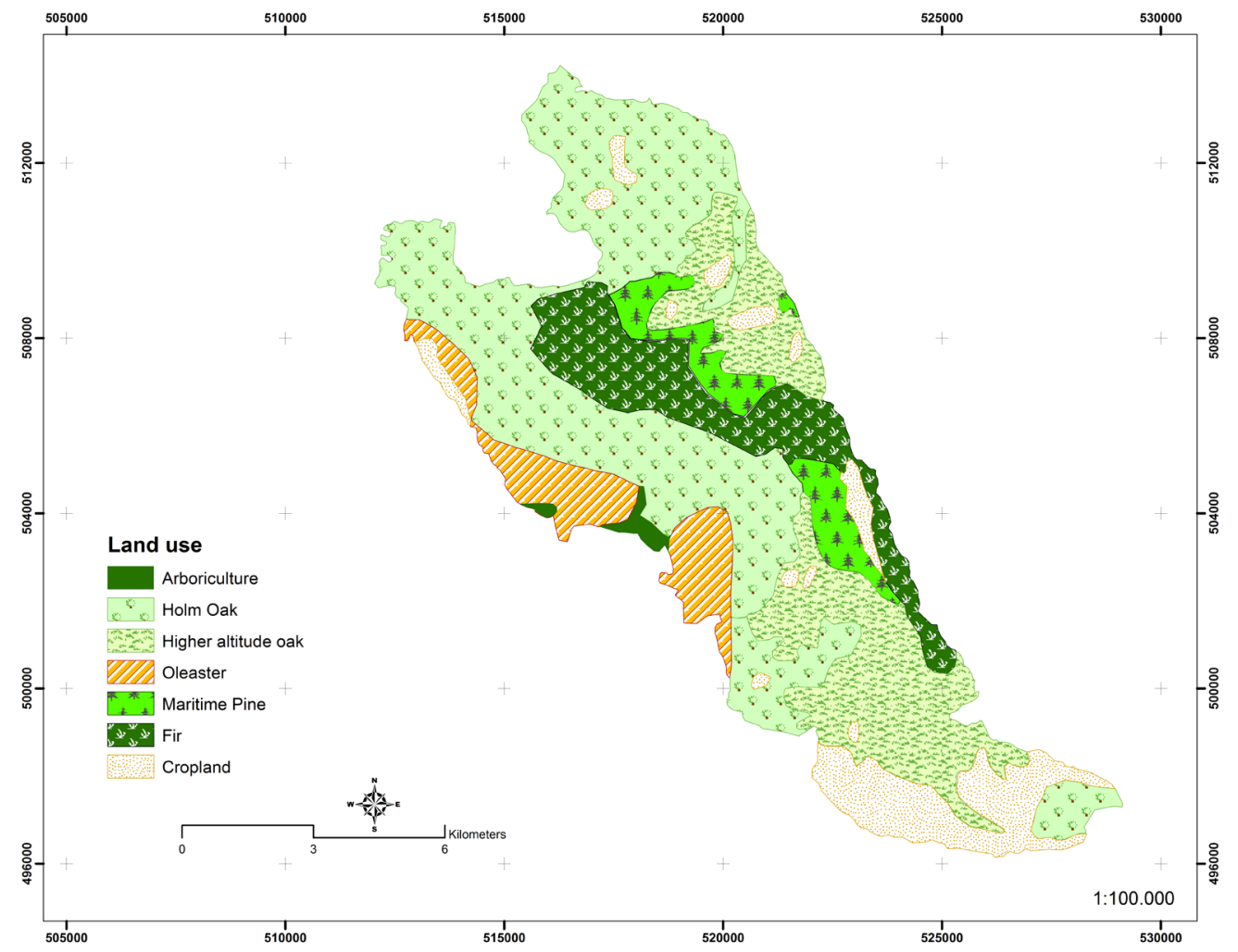

Figure 6. Land use map. 


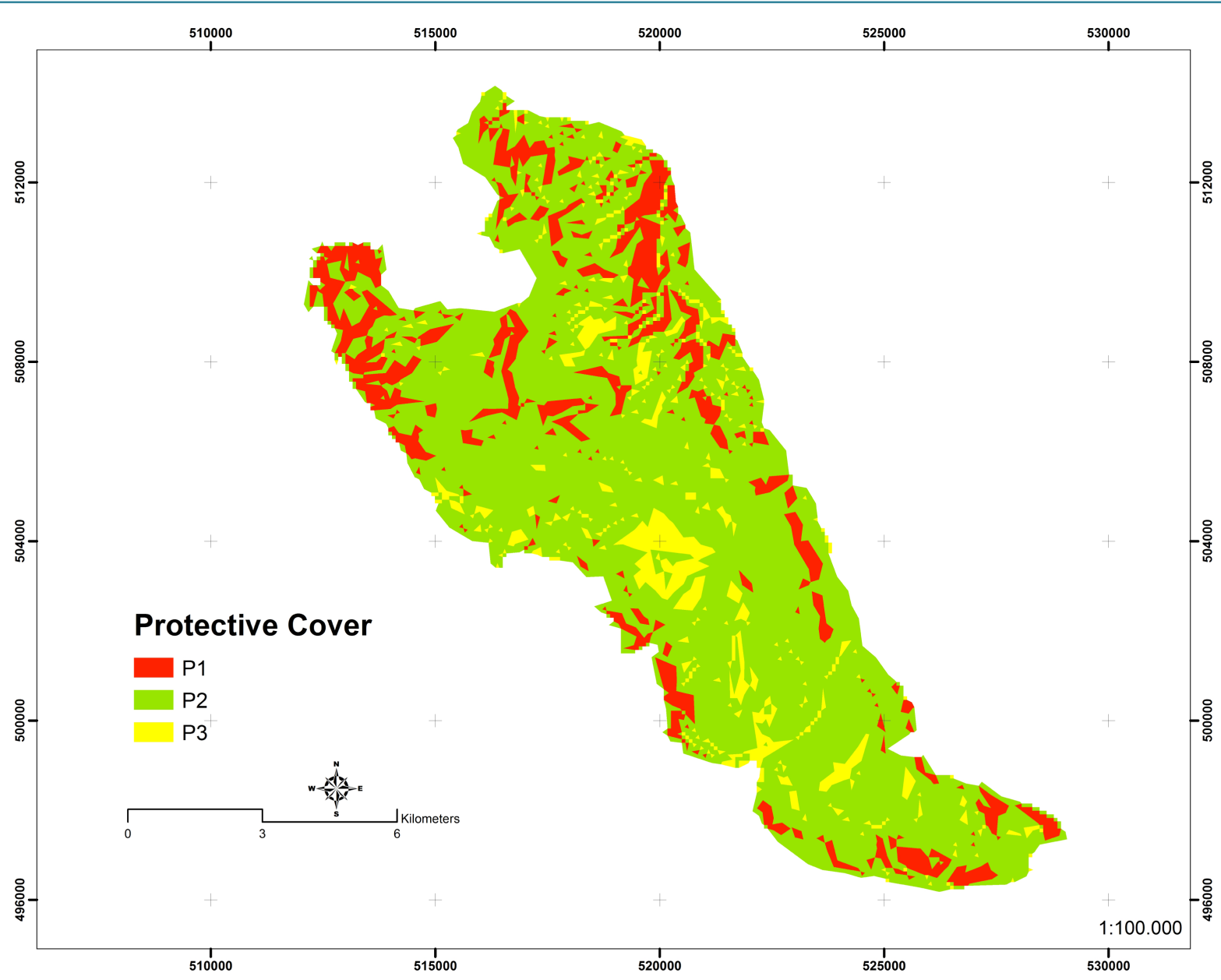

Figure 7. Protective cover map.

\subsection{Infiltration Condition (I)}

The infiltration condition parameter was evaluated based on the combination of digital elevation model (DEM) and the land-use map. Steep slopes and poor vegetation leads to higher vulnerability, because it is assumed that there is more runoff that will infiltrate in the flow relief areas [4]. The indexed class I1 presents the higher vulnerability, it was assigned to areas of concentrated infiltration like sinkholes, caves and swallow holes. The majority of the study area is indexed I3 and I4 (Figure 8), which I3 corresponds to the area where the slope is greater than $10 \%$ for cultivated area and greater than $25 \%$ pasture where runoff water infiltrates, and I4 forms the rest of catchment.

\subsection{Karst Network Development (K)}

Vulnerability is evaluated in terms of the presence of a karstic network and the degree to which the network is developed [5]. The karstic landforms such as sinkholes, caves and swallow holes constituted the first indicator of a karst system. Another indicator is provided by the lot of springs present in the study area. According to [13], a poorly developed system will very often possess many springs. This concept is based on the hypothesis that there is a karstic network hierarchy. In light of the above, the entire catchment of these springs has been indexed into K2.

\subsection{Protection Zone Map}

The raster calculator geoprocessing tool in ArcGis was used to create and execute a vulnerability map (Figure 9) by overlaying the previous four layers according to the relation (1). 


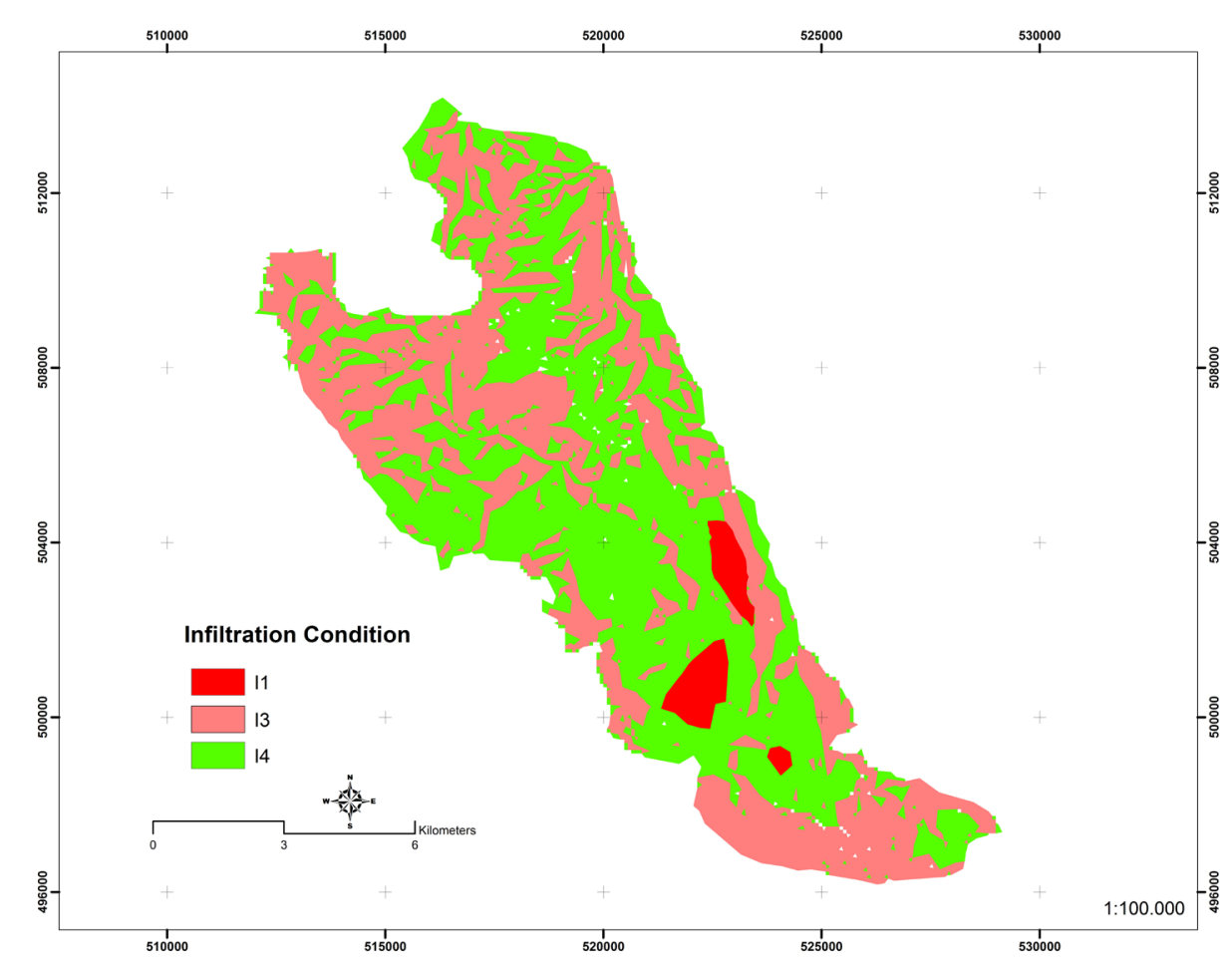

Figure 8. Infiltration condition map.

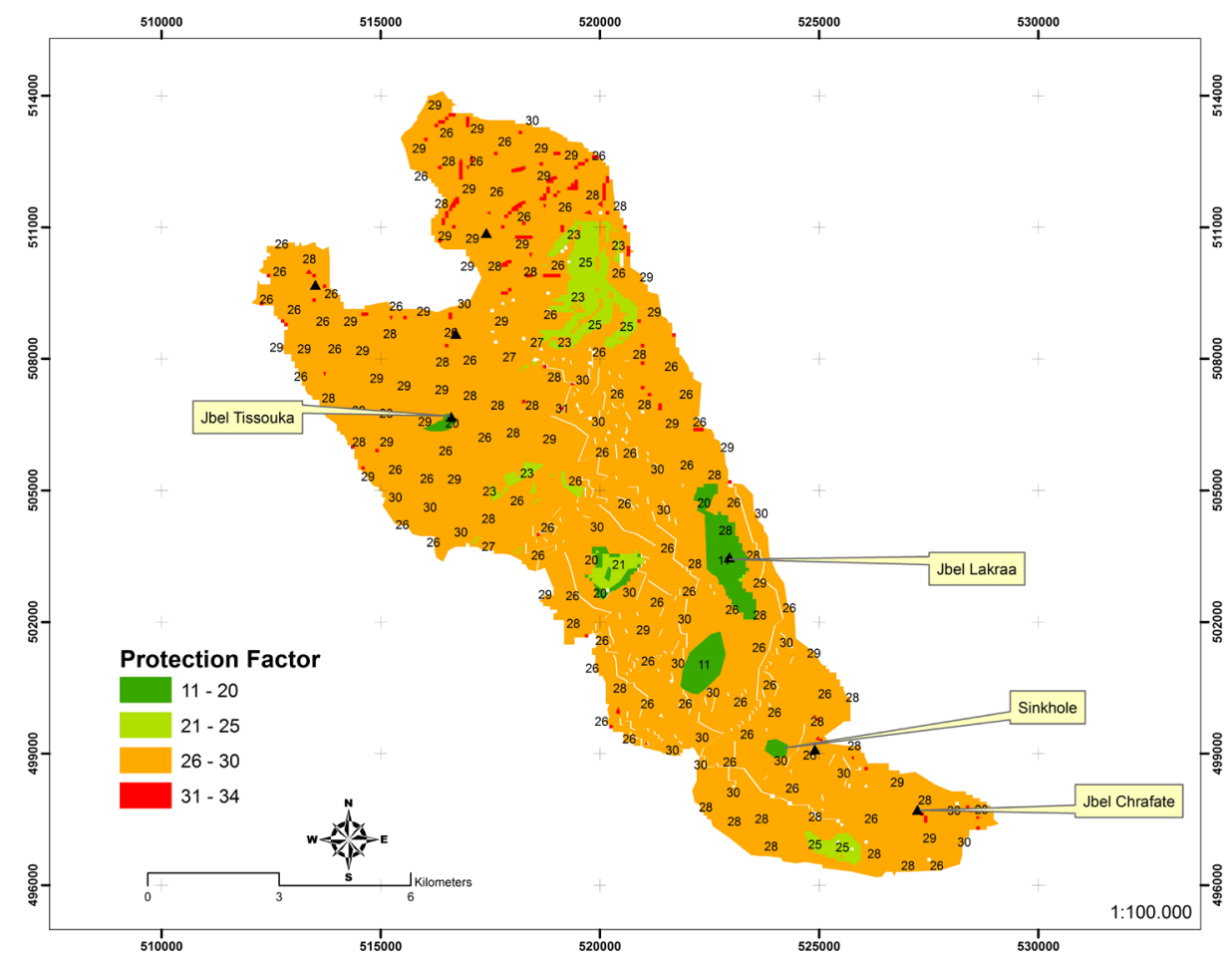

Figure 9. Groundwater vulnerability map.

The F protection factor values may be divided into four classes of vulnerability: very high (9 - 20), high (20 25), moderate (25 - 30) and low (30 - 34). The Reclassify tool in ArcGis software allows representing these intervals of protection factor in a protection zone map (Figure 10). 


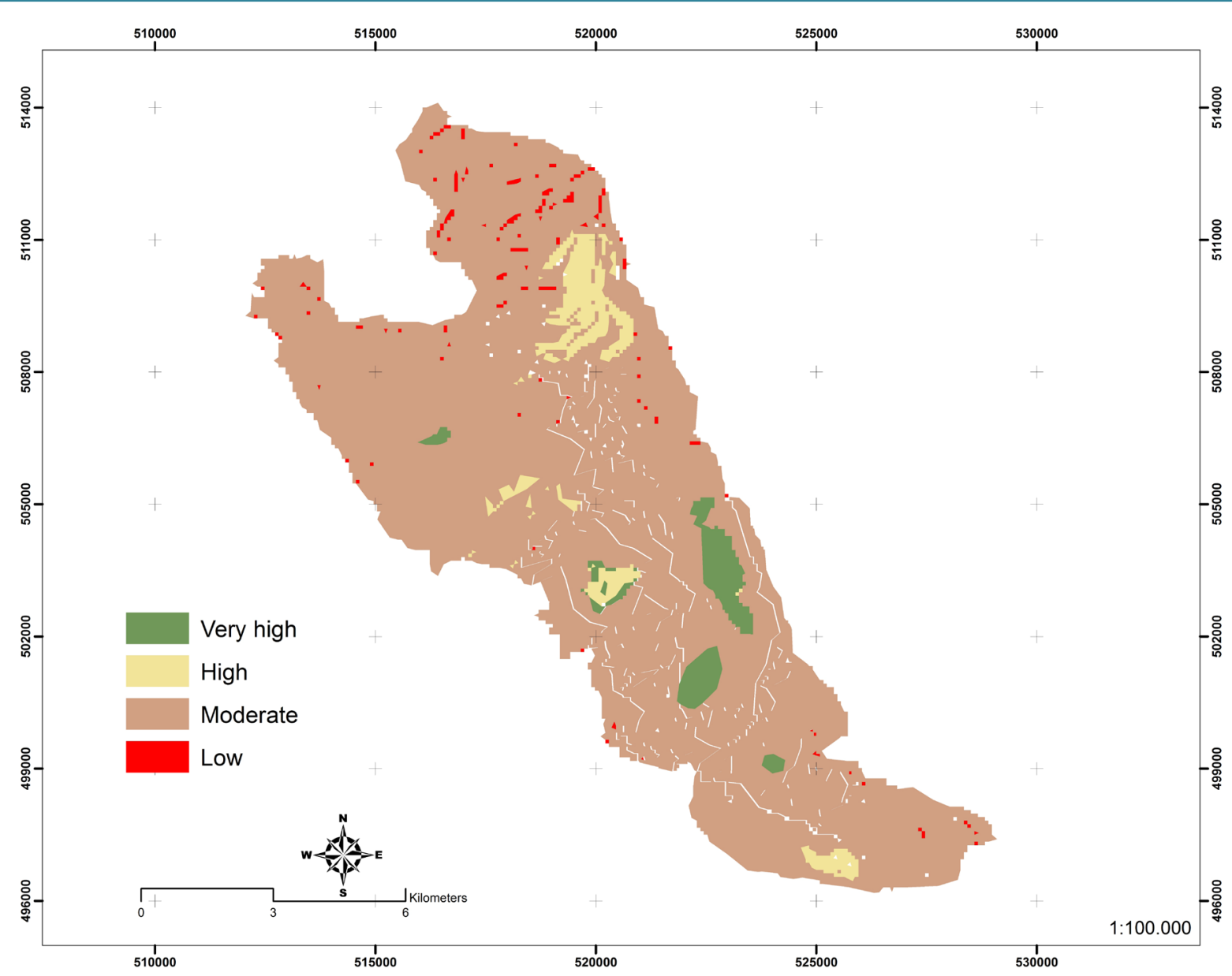

Figure 10. Protection zone map.

\section{Conclusions}

This study reveals that the use of Geographic Information System (GIS) is an effective tool to assess the groundwater vulnerability in the calcareous dorsal, to the west of Chefchaouen City. Four parameter layers were established in GIS environment and the vulnerability map was created using raster calculator tool of ArcGis software according to the relation (1).

The protection zone map highlighted that the study area shows aquifer vulnerability that ranges from moderate to very high. The highest contribution to vulnerability was due to karstic landforms such as sinkholes, caves and swallow holes.

\section{References}

[1] Ford, D.C. and Williams, P.W. (1989) Karst Geomorphology and Hydrology. Chapman and Hall, London, 601 p. http://dx.doi.org/10.1007/978-94-011-7778-8

[2] Aboufirassi, M., ElHebil, A., El Mandour, A., Amrhar, M., Bahir, M., Errouane, S., Fakir, Y., Laftouhi, N.E. and Quortobi, M. (1991) Hydrologie des milieux fissurés: Milieux carbonatés et milieux de socle. Eauet Développement, 11, 62-68.

[3] Struckmeier, M., Rubin, Y. and Jones, J.A. (2005) Groundwater-Reservoir for a Thirsty Planet? Planet Earth, Inter- national Union of Geological Sciences y United Nations Educational Scientific and Cultural Organisation, Leiden.

[4] Doerfliger, N., Jeannin, P.Y. and Zwahlen, F. (1999) Water Vulnerability Assessment in Karst Environments: A New Method of Defining Protection Areas Using Multi-Attribute Approach and GIS Tool (EPIK Method). Environmental Geology, 39, 165-172. http://dx.doi.org/10.1007/s002540050446

[5] Doerfliger, N. and Zwahlen, F. (1998) Groundwater Vulnerability Mapping in Karstic Regions (EPIK), Practical Guide. 
Swiss Agency for the Environment, Forests and Landscape (SAEFL), Berne, 56.

[6] Nold, M., Uttinger, J. and Wildi, W. (1981) Géologie de la dorsale calcaire entre Tétouan et Assifane (Rif interne, Maroc). Notes et mémoires du Service Géologique du Maroc. Rabat, No. 300.

[7] El Bardai, R., Targuisti, K., Hlila, R. and Aluni, K. (2014) The Fracturing Role in the Conditioning of Karst Groundwater Circulations in the Calcareous Dorsal (Northern Rif, Morocco). International Journal of Innovation and Applied Studies, 6, 825-838.

[8] Zwahlen, F. (2004) Vulnerability and Risk Mapping for the Protection of Carbonate (Karst) Aquifers, COST Action 620, Final Report. European Commission Directorate-General XII, Science, Research and Development, Report EUR 20912, COST Action 620, Luxembourg, Belgium, 297 p.

[9] Doummar, J., Margane, A., Geyer, T. and Sauter, M. (2012) Vulnerability Mapping Using the COP and EPIK Methods. Technical Report n 7b. Protection of the Jeita Spring, $42 \mathrm{p}$.

[10] Doerfliger, N. and Zwahlen, F. (1997) EPIK: A New Method for Outlining of Protection Areas in Karstic Environment. IntSymp on Karst Water and Environmental Impacts, Antalya, Turkey. Balkema, Rotterdam, 117-123.

[11] SAEFL (2000) Groundwater Vulnerability Mapping in Karstic Regions (EPIK). Practical Guide. Environment in Practice. SAEFL, Berne, 56-57.

[12] Williams, P.W. (2008) The Role of the Epikarst in Karst and Cave Hydrogeology: A Review. International Journal of Speleology, 37, 1-10. http://dx.doi.org/10.5038/1827-806X.37.1.1

[13] Mangin, A. (1975) Contribution à l'étude hydrodynamique des aquifères karstiques. Annales de Spéléologie, 26, 283339. 